\title{
Comparative Effect of The Inclusion of Zootechnical Additives in the Feed of Japanese Quails in Two Productive Phases
}

\author{
MARINA J. LEMOS ${ }^{1,2}$, LÍGIA F.L. CALIXTO ${ }^{2}$, DANIELE S. SOUZA ${ }^{3}$, TÚLIO L. \\ REIS $^{2}$, APARECIDA A. NASCIMENTO ${ }^{2}$ and CARLOS A. OLIVEIRA ${ }^{2}$ \\ ${ }^{1}$ Centro Universitário Claretiano, Rua Oto de Alencar, 23, Maracanã, 20271-220 Rio de Janeiro, RJ, Brazil \\ ${ }^{2}$ Departamento de Produção Animal, Instituto de Zootecnia, Universidade Federal Rural \\ do Rio de Janeiro, BR 465, Km 07, 23890-000 Seropédica, RJ, Brazil \\ ${ }^{3}$ Departamento de Nutrição Animal, Universidade Estadual Paulista Júlio de Mesquita Filho/FMVZ, \\ Av. Prof. Mário Rubens Guimarães Montenegro, s/n, 18618-687 Botucatu, SP, Brazil
}

Manuscript received on October 18, 2017; accepted for publication on January 3, 2018

\begin{abstract}
This study aimed to evaluate the intestinal morphology, performance and financial analysis of the inclusion of additives in the feed during the productive period of 360 Japanese quails distributed in a completely randomized design in a split plot scheme in time with five treatments and eight repetitions of nine birds each. The treatments were: control, antibiotic, prebiotic, probiotic and synbiotic. The variables were: height, width and width/height ratio of the villi, crypt depth and villus/crypt ratio, feed intake, egg production, egg weight average, egg mass, feed conversion per mass and per dozen eggs and viability, internal rate of return, net present value and cost benefit. The additives in the feed increased height and width of the villi, decreased crypt depth and increased villus/ crypt ratio compared to the control. Feed intake was lower after the inclusion of antibiotics and synbiotics in the feed. Egg production and feed conversion improved after the inclusion of additives in the feed compared with the control. The reduction of feed intake was more pronounced with the addition of antibiotic and synbiotic in the final stage of the productive period of the Japanese quails. The inclusion of antibiotics and synbiotic proved to be more financially viable.
\end{abstract}

Key words: antibiotic, intestinal morphology, prebiotic, probiotic, symbiotic.

\section{INTRODUCTION}

The consumption of quail eggs has been growing in recent years, from 13 quail eggs / inhabitant / year in 2010 (Bertechini 2012) to 27 quail eggs / inhabitant / year in 2015 (Marques and Antunes 2015). Increased production is boosting consumption and reflecting in the price of eggs, making them more accessible to different social classes.

Correspondence to: Marina Jorge de Lemos

E-mail: marijorgelemos@hotmail.com
According to the IBGE (2014), the number of quails in 2014 was of 20.34 million heads and egg production was equivalent to 392.73 million dozens, an increase of $14.7 \%$ in relation to data registered in 2013. This growth was due to the use of new technologies, experience of the poultry industry in terms of production and marketing and due to investments in the areas of health, management, genetic enhancement and nutrition.

The inclusion of additives in the poultry feed has become one of the alternatives that have 
contributed to the progress made in the the area of nutrition, and the antibiotics used as performance enhancing additives are responsible for the high productivity levels in broiler chickens.

In the poultry laying industry, positive impact of performance enhancers has prioritized the reduction of harmful effects caused by extreme stress conditions imposed by long productive periods and the discomfort of the laying premises, conditions that worsen the laying coturniculture process, as quails are birds that are more easily stressed because of their hectic and nervous behavior which affects their well-being and compromises their intestinal health, triggering declines in performance.

With the progressive ban on the use of antibiotics as performance enhancers in many countries, the poultry industry has been intensifying research using alternative substances such as prebiotics, probiotics and synbiotics. Performance-enhancing antibiotics are included in the animals diet in subtherapeutic dosages, and in general, their mechanisms of action are: control of endemic subclinical infections, reducing the "metabolic cost" of chronic immune system activation; reduction of growth-depressant metabolites generated by the intestinal microbiota; reduction of nutrient utilization by the intestinal microbiota (reduction of compettion for nutrients) and improvement of nutrient absorption and utilization (Preis et al. 2013).

Prebiotics are carbohydrates that stimulate the growth and/or activity of a limited number of bacteria (such as bifidobacteria and lactobacilli, which are known to have a high capacity to produce lactic and acetic acids, which promote the decrease of $\mathrm{pH}$ in the digestive system, thus causing inhibition of the development of harmful bacteria populations, such as Escherichia coli, Clostridium sp. and Salmonella sp., which thrive in acid environments) and beneficially affect host health (Mathew et al. 1993, Flickinger et al. 2003, Roberfroid et al. 2010).
The main role of probiotics is competitive exclusion, in which the probiotic competes with pathogenic bacteria for binding sites on the intestinal surface forming a physical barrier, thus excluding the pathogen and preventing its colonization, and toxin production (Furlan et al. 2004, Cantarelli et al. 2005).

The synbiotics are elaborated by the association of probiotics and prebiotics in a single product, aiming at a potentiating effect. The symbiotic action stabilizes the intestinal environment and increases the number of beneficial bacteria producing lactic acid, favoring the eubiosis situation (Furlan et al. 2004).

The use of these alternative substances is already a reality in Brazil, and different answers on the use of these substances have been reported regarding laying hens; yet, few data have been collected on the zootechnical advantages of including theses additives throughout the productive period of the quails. Based on this context, the present study aimed to comparatively evaluate the effects of inclusion of antibiotic, prebiotic, probiotic and synbiotic additives in the feed on the intestinal morphology, performance and analysis of the financial viability throughout the productive period of Japanese quails.

\section{MATERIALS AND METHODS}

The experiment was conducted in the experimental shed in the aviculture section of the Universidade Federal Rural do Rio de Janeiro (UFRRJ) from May 2014 to January 2015.

The management conditions and the experimental procedures adopted were submitted and approved by ECUA (Ethics Committee on the Use of Animals), protocol no. 352/2013, da Universidade Federal Rural do Rio de Janeiro.

Three hundred and sixty Japanese quails (Coturnix coturnix japonica), with 35 days of age and initial weight of $125.09 \mathrm{~g}$, distributed in 
a completely randomized design in a split plot scheme in time (from 9 to 23 weeks of age, from the early productive period to the end of the productive peak and from 24 to 39 weeks of age, from between the post peak and the end of the productive period) with five treatments and eight repetitions of nine birds each were used.

The treatments consisted of five experimental diets formulated to meet the nutritional requirements of Japanese quails in the productive phase according to Rostagno et al. (2011) (Table I). They were denominated according to the type of additive tested and distributed as follows: Control - reference diet without inclusion of additives; Antibiotic - reference diet $+147 \mathrm{~g} / \mathrm{t}$ of antibiotic; Prebiotic - reference diet $+1.5 \mathrm{~kg} / \mathrm{t}$ of prebiotic; Probiotic - reference diet $+300 \mathrm{~g} / \mathrm{t}$ of probiotics; Synbiotic - reference diet + synbiotic (probiotic + prebiotic).

The levels of additives were used according to the type, for example, the probiotic was used according to the manufacturer's recommendations, the antibiotic according to the MAPA recommendations for laying hens, the prebiotic was used based on the best results from previous studies that also used quails throughout the productive period (Lemos et al. 2014) and the synbiotic, considering the levels of probiotic and prebiotic used. All additives were added to replace the equivalent in weight of inert material (kaolin), adjusting itself to the percentage composition of the experimental feed, which allowed the maintenance of the same nutritional levels in all diets. The prebiotic additive used was rich in $\beta$-glucans and mannanoligosaccharides derived from the yeast Saccharomyces cerevisiae, with $31.30 \%$ of protein, $34.82 \%$ of $\beta$-glucans and $20.94 \%$ of mannanoligosaccharides. The probiotic was composed of Bacillus subtilis $\left(10^{9} \mathrm{CFU} / \mathrm{g}\right)$ and the active ingredient of the antibiotic used was Zinc bacitracin 15\%.
Feed and water were provided ad libitum throughout the experimental period. The poultry was weighed on the first day of the experiment and housed in cages in a completely randomized design at 35 days of age and therefore receiving rearing feed in order to meet the nutritional requirements of Japanese quails in the rearing phase according to Rostagno et al. (2011). When they completed 42 days of age, the experimental feed was provided and the light program with the aid of an automatic timer initialized; it was provided an initial supply of 14 hours of daily light, having weekly increases of 30 minutes until reaching 16 hours of daily light, remaining in that amount until the end of the experimental period. The poultry remained in the process of adaptation to the experimental feed for three weeks and when 63 days of age were completed, the data collecting began.

The variables evaluated for intestinal morphology were: height, width and width/height ratio of the villi, crypt depth and villus / crypt ratio; for performance: feed intake ( $\mathrm{g} / \mathrm{bird} / \mathrm{day}$ ), egg production (\%), egg weight average ( $\mathrm{g}$ ), egg mass (g), feed conversion per mass and per dozen eggs and viability; financial analysis was computed by the internal rate of return (IRR), net present value (NPV) and cost benefit (C:B).

For morphological evaluation, eight quails per treatment (one bird per repetition) were euthanized by cervical dislocation at 39 weeks of age according to the method described by Pelicano et al. (2005). At this time, samples of approximately $2.0 \mathrm{~cm}$ of segments of the intestine (duodenum, jejunum and ileum) were removed from each bird, and from these samples were selected stretches of the middle portion of each segment, which were fixed in Bouin solution and maintained in absolute alcohol until the end of the cutting process. For realization of cuts and preparation of the slides, the segments were dehydrated in ascending series of alcohols, diaphanized in xylene and fixed in paraffin. Using light microscopy at increase of $2.5 \mathrm{X}$, the captured 
TABLE I

Percentage and calculated composition of experimental reference diet for Japanese quails in the production phase.

Ingredients (\%)

\begin{tabular}{lc}
\hline Corn $(8.62 \% \mathrm{CP})$ & 57.740 \\
Soybean meal $(45.32 \% \mathrm{CP})$ & 32.670 \\
Soy oil & 0.674 \\
Common salt & 0.349 \\
Calcium calcareous & 6.578 \\
Dicalcium phosphate & 1.053 \\
Vitamin mix $^{1}$ & 0.100 \\
Mineral mix $^{2}$ & 0.100 \\
DL-Methionine $(99 \%)$ & 0.326 \\
L-Lysine HCL $(78 \%)$ & 0.155 \\
Choline chloride $(60 \%)$ & 0.035 \\
kaolin & 0.220 \\
\hline Total & 100 \\
\hline
\end{tabular}

Nutritional composition calculated

\begin{tabular}{lc}
\hline Metabolizable energy (kcal/kg) & 2800.00 \\
Crude protein (CP\%) & 20.166 \\
Calcium (Ca\%) & 2.909 \\
Phosphorus available (\%) & 0.303 \\
Chlorine (\%) & 0.240 \\
Lysine Digestible (\%) & 1.064 \\
Lysine Total (\%) & 1.174 \\
Methionine + Cystine digestible (\%) & 0.873 \\
Methionine + Cystine total (\%) & 0.951 \\
Methionine digestible(\%) & 0.604 \\
Methionine total (\%) & 0.633 \\
Potassium (\%) & 0.774 \\
Sodium (\%) & 0.178 \\
Threonine digestible (\%) & 0.671 \\
Threonine total (\%) & 0.772 \\
Triptofano digestible (\%) & 0.223 \\
Triptofano total (\%) & 0.247 \\
\hline
\end{tabular}

Composition per $\mathrm{kg}$ of product 1.2: 1 Vitamin mix: Vit. A-12,000.000 IU; Vit. D3 - 3,600.000 I; Vit. E-3,500 IU; Vit. B1 - 2,500mg; Vit. B2 - 8,000mg; Vit. B6-5,000mg; pantothenic acid - 12,000mg; biotin - 200mg; Vit. K-3,000mg; folic acid - 1,500mg; nicotinic acid - 40,000mg; Vit. B 12 22,000 mg; Se - 150mg; vehicle q.s.p. - 1,000g; 2 Mineral mix: Mn - 160g; Fe-100g; Zn - 100g; Cu-20g; Co-2g; I-2g; vehicle q.s.p. $-1,000 \mathrm{~g}$. images were analyzed with the help of the Image J-Pro Plus 4.0 software. The analysis methodology used was described by Oliveira et al. (2000).

In each tissue were measured: Villi Height Only villi with visible set and defined epithelium were measured. Five villi by histological section were selected in 10 different sections, with a minimum distance of 100 micrometres between them, a total of 50 villi per animal, using images captured with a $10 \mathrm{X}$ objective; Villi width - The width of the villi was measured by taking the average of the three points used in the same villus height measurement, in the apical, middle and basal regions; Width/ height ratio of the Villi - it was determined by the ratio between height and width of each villus in every segment of the small intestine (duodenum, jejunum and ileum); Crypt depth - five crypts per section were selected in 10 different sections, with a minimum distance of 100 micrometres between them, total of 50 villi per animal. The images used were obtained with a $10 \mathrm{X}$ objective; Villus / crypt ratio - it was determined by the ratio between the villus height and crypt depth of that same villus in every segment of the small intestine (duodenum, jejunum and ileum).

For performance evaluation, egg weight was recorded every 21 days for three consecutive days, considering all the eggs produced by treatment / repetition on the day. The measurement of weight was performed on a digital scale with a precision of $0.01 \mathrm{~g}$. At the end of the experiment, the average of the values obtained in each period was calculated. For the feed intake control, feed of each repetition was packed in plastic buckets, properly identified, being measured once a week by the difference between the feed provided and by what was left in the buckets and feeders. At the end of each period an average was calculated to determine the feed intake. In the event of death, the feed from the feeders was weighed to calculate the corrected intake. The egg production percentage $(\%)$ was performed based on the daily production 
of eggs for each treatment / repetition obtaining the average of each period. The egg mass ( $g$ ) was recorded based on the egg production average (unit) in the period multiplied by the egg weight average for each treatment / repetition in the same period. The calculation of feed conversion per dozen eggs was obtained considering the total feed intake $(\mathrm{kg})$ in the period, divided by the sum of total egg production in dozens for each treatment / repetition in the same period. For the feed conversion per mass of the eggs produced was considered the total feed intake $(\mathrm{kg})$ of each treatment / repetition in the period divided by the egg mass $(\mathrm{kg})$ of the same period. The viability of the birds was obtained by the ratio between the number of live birds at the end and beginning of each period, and expressed as a percentage.

The financial analysis considered data from the feed intake per treatment, egg production per treatment, feed conversion per dozen and per mass per treatment, cost of the feed per treatment, amount paid to producers for quail eggs and costs commonly seen in the production of quails. To evaluate the costs per $\mathrm{kg}$ of the feed of each treatment was considered the average price of ingredients (corn, soybean meal, limestone, dicalcium phosphate, soybean oil, salt, mineral and vitamin mixture, DLmethionine, L-lysine $\mathrm{HCl}$, choline chloride and additives (price in Dollar converted to Real)) in the state of Rio de Janeiro. The IRR (internal rate of return), the NPV (net value of the product) and the cost benefit of using different additives in the feed of quails were obtained.

Statistically, the data of the variables from the intestinal morphology were analyzed considering the total procuctive period of the quail (from 9 to 39 weeks of age) and the performance variables were analyzed considering the periods, according to a split plot scheme. The results were submitted to analysis of variance using the BioEstat ${ }^{\circledR}$ Program. Subsequently, to evaluate the effect of treatments and periods the Tukey test and F-test at $5 \%$ probability were applied, respectively, to compare the averages.

\section{RESULTS AND DISCUSSION}

Table II refers to the height, width, width / height ratio of the villi, depth of intestinal crypts and villus/crypt ratio of the different segments of the small intestine (duodenum, jejunum and ileum) of Japanese quails fed diets containing different additives throughout the productive period.

The height and width of the intestinal villi in all segments of the small intestine of the Japanese quails increased significantly $(\mathrm{P}<0.05)$ after the inclusion of different additives in the feed compared with the control. The incorporation of antibiotic or synbiotic promoted the highest averages of height and width of the intestinal villi compared with the other treatments $(\mathrm{P}<0.05)$ (Table II).

The supply of performance enhancers antibiotics and synbiotic reduces the intestinal pathogenic microbial load by reducing the presence of toxins and eliminates its negative effect on intestinal mucosa allowing improvement in intestinal morphology, increasing the height and width of the villi and also the absorption area of nutrients (Abdelgader et al. 2012).

The results found in this study for height and width of the intestinal villi corroborate those found by Çakir et al. (2008) who when researching the influence of additives containing synbiotic, organic acid and antibiotics on the intestinal morphology of Japanese quails, observed an increase in villi height in the segments of the small intestine in quails supplemented with various additives compared to the control treatment (no additives). Abdelgader et al. (2012) observed an increase in the height of intestinal villi of laying hens after including synbiotic in the feed. These authors suggest that a combination of probiotic and prebiotic modulates the composition of the intestinal microbiota, reducing the number of pathogenic bacteria and 
TABLE II

Morphology of the intestinal segments of Japanese quails fed diets containing different additives during the productive period (9-39 weeks of age).

\begin{tabular}{|c|c|c|c|}
\hline \multirow{3}{*}{ Treatments } & \multicolumn{3}{|c|}{ Variables } \\
\hline & \multicolumn{3}{|c|}{ Height of intestinal villi $(\mu \mathrm{m})$} \\
\hline & Duodenum & Jejunum & Ileum \\
\hline Control & $302.251 \mathrm{c}$ & $262.372 \mathrm{c}$ & $236.160 \mathrm{c}$ \\
\hline Antibiotic & $440.472 \mathrm{a}$ & $355.124 \mathrm{a}$ & $324.752 \mathrm{a}$ \\
\hline Probiotic & $411.254 \mathrm{~b}$ & $322.362 \mathrm{~b}$ & $293.620 \mathrm{~b}$ \\
\hline Prebiotic & $412.761 \mathrm{~b}$ & $325.410 \mathrm{~b}$ & $294.652 \mathrm{~b}$ \\
\hline Synbiotic & $439.616 \mathrm{a}$ & $352.751 \mathrm{a}$ & $319.536 \mathrm{a}$ \\
\hline \multirow[t]{3}{*}{$\mathrm{CV} \%$} & 9.41 & 7.28 & 8.11 \\
\hline & \multicolumn{3}{|c|}{ Width of intestinal villi $(\mu \mathrm{m})$} \\
\hline & Duodenum & Jејunum & Ileum \\
\hline Control & $32.281 \mathrm{c}$ & $31.262 \mathrm{c}$ & $30.271 \mathrm{c}$ \\
\hline Antibiotic & $46.221 \mathrm{a}$ & $44.833 \mathrm{a}$ & $42.914 \mathrm{a}$ \\
\hline Probiotic & $43.642 \mathrm{~b}$ & $40.137 \mathrm{~b}$ & $38.336 \mathrm{~b}$ \\
\hline Prebiotic & $44.352 \mathrm{~b}$ & $41.662 \mathrm{~b}$ & $38.291 \mathrm{~b}$ \\
\hline Synbiotic & $45.930 \mathrm{a}$ & $44.090 \mathrm{a}$ & $41.695 \mathrm{a}$ \\
\hline \multirow[t]{3}{*}{$\mathrm{CV} \%$} & 7.68 & 8.34 & 9.71 \\
\hline & \multicolumn{3}{|c|}{ Width / height ratio of the intestinal villi $(\mu \mathrm{m})$} \\
\hline & Duodenum & Jejunum & Ileum \\
\hline Control & 0.107 & 0.119 & 0.128 \\
\hline Antibiotic & 0.105 & 0.126 & 0.132 \\
\hline Probiotic & 0.106 & 0.124 & 0.130 \\
\hline Prebiotic & 0.107 & 0.128 & 0.130 \\
\hline \multirow{4}{*}{$\begin{array}{c}\text { Synbiotic } \\
\text { CV \% }\end{array}$} & 0.105 & 0.125 & 0.131 \\
\hline & 9.47 & 8.65 & 8.53 \\
\hline & \multicolumn{3}{|c|}{ Depth of intestinal crypts $(\mu \mathrm{m})$} \\
\hline & Duodenum & Jejunum & Ileum \\
\hline Control & $49.351 \mathrm{a}$ & $45.110 \mathrm{a}$ & $43.531 \mathrm{a}$ \\
\hline Antibiotic & $43.544 \mathrm{~b}$ & $41.678 \mathrm{~b}$ & $40.015 \mathrm{~b}$ \\
\hline Probiotic & $45.692 \mathrm{~b}$ & $42.966 \mathrm{~b}$ & $41.985 \mathrm{~b}$ \\
\hline Prebiotic & $44.548 \mathrm{~b}$ & $42.124 \mathrm{~b}$ & $41.682 \mathrm{~b}$ \\
\hline Synbiotic & $44.133 \mathrm{~b}$ & $42.081 \mathrm{~b}$ & $40.370 \mathrm{~b}$ \\
\hline \multirow[t]{3}{*}{$\mathrm{CV} \%$} & 8.62 & 9.84 & 9.55 \\
\hline & \multicolumn{3}{|c|}{ Villus / crypt ratio $(\mu \mathrm{m})$} \\
\hline & Duodenum & Jejunum & Ileum \\
\hline Control & $6.125 \mathrm{~b}$ & $5.816 \mathrm{~b}$ & $5.425 \mathrm{~b}$ \\
\hline Antibiotic & $10.116 \mathrm{a}$ & $8.521 \mathrm{a}$ & $8.116 \mathrm{a}$ \\
\hline Probiotic & $9.002 \mathrm{a}$ & $7.502 \mathrm{a}$ & $6.993 \mathrm{a}$ \\
\hline Prebiotic & $9.273 \mathrm{a}$ & $7.725 \mathrm{a}$ & $7.069 \mathrm{a}$ \\
\hline Synbiotic & $9.960 \mathrm{a}$ & $8.383 \mathrm{a}$ & $7.915 \mathrm{a}$ \\
\hline $\mathrm{CV} \%$ & 7.96 & 7.54 & 8.37 \\
\hline
\end{tabular}

Averages followed by the same letter in the column do not differ by Tukey test at $5 \%$ probability. CV - Coefficient of variation. Antibiotic - Bacitracin Zinc; Prebiotic - mannanoligosaccharides and $\beta$-glucans based; Probiotic - Bacillussubtilis based; Synbiotic - prebiotic + probiotic used. 
increasing the number of beneficial bacteria, leading to improvements in morphology and absorption of nutrients.

The width / height ratio of intestinal villi was not affected. According to the literature the smaller the proportion the greater the area of intestinal absorption (Kisielinski et al. 2002). Lemos et al. (2014) observed higher width / height ratio of intestinal villi after inclusion of prebiotic in the feed of Japanese quails.

The crypt depth in all segments of the small intestine decreased after the inclusion of different additives in the feed of Japanese quails $(\mathrm{P}<0.05)$ compared to the control treatment (no additives) (Table II). Changes in crypt depth, for example, increased depth, may indicate high proliferative cell activity, which generally occurs as the epithelium response to any injury to the mucosa and seeks to maintain the height of the villi (Furlan et al. 2004). Since this response requires energy and protein, lower crypt depth is a good intestinal health indicator because it requires few nutrients for cell renewal. With little renewal, the intestinal cells become more mature and, consequently, the production of digestive enzymes and absorption of nutrients is more efficient (Furlan et al. 2004, Ibrahim 2011).

Similar to that seen in the present study, Bueno et al. (2012) evaluated the influence of probiotic supplementation on the intestinal morphology of Japanese quails and observed lower crypt depth in quails supplemented with probiotics compared to the control treatment (without supplementation).

The villus / crypt ratio was greater in the intestine of quails fed diets containing additives ( $\mathrm{P}<0.05)$ compared to the control treatment (no additives) (Table II). The increase in villus / crypt ratio follows the behavior observed in this study for villi height and crypt depth. A greater villus / crypt ratio, which is correlated with increased villus height and lower crypt depth, indicates a better state of intestinal health (Viola and Vieira 2007).
Table III relates the values of feed intake, egg production, egg weight average, egg mass, feed conversion per dozen and per egg mass and viability of Japanese quails fed diets supplemented with different additives at two periods during the productive phase.

The inclusion of antibiotic and synbiotic proved to be more efficient in providing a reduction in feed intake than the other additives $(\mathrm{P}<0.05)$ in both periods analyzed. Analyzing the two productive periods, the inclusion of additives, regardless of type, was more effective in reducing feed intake (Table III, Figure 1) from 24 to 39 weeks of age when compared to the period of 9 to 23 weeks of age $(\mathrm{P}<0.05)$; no effect was observed for the period $(\mathrm{P}>0.05)$ on feed intake of the quails on the control treatment, which maintained higher feed intake during the entire productive period.

According to Furlan et al. (2004) and Abdelgader et al. (2012), an improvement in the integrity of the intestinal mucosa, as was observed in this study in quails that received additives, may provide a better nutrient absorption area, justifying thus less need for feed intake for these birds to meet their nutritional requirements compared with the control which received no additives.

The same result was seen regarding the intestinal integrity in birds fed these same additives, justifying thus the best efficiency of these additives in the variable studied. With regard to the best observed efficiency with antibiotic use, the literature (Huyghebaert and Groote 1997, Abdelgader et al. 2012) mentions that zinc bacitracin operates mainly in reducing bacteria of the genus Clostridium and their toxins, and the reduction of these toxins that cause injuries to the intestinal mucosa, it improves integrity and absorption of nutrients as well, thereby promoting reduction in feed intake. The best effect observed by using synbiotic can be justified by its enhancing function, manifested by the joint action of the two additives (probiotic + prebiotic) thereby 
TABLE III

Performance of Japanese quails fed diets containing different additives in two periods during the productive period.

\begin{tabular}{|c|c|c|c|}
\hline \multirow{3}{*}{ Treatments } & \multicolumn{2}{|c|}{ Variables } & \multirow{3}{*}{ Average } \\
\hline & \multicolumn{2}{|c|}{ Feed Intake (g/bird/day) } & \\
\hline & 9 to 23 weeks & 24 to 39 weeks & \\
\hline Control & $25.924 a$ & $25.552 \mathrm{a}$ & 25.738 \\
\hline Antibiotic & $24.221 \mathrm{cA}$ & $23.421 \mathrm{cB}$ & 23.821 \\
\hline Probiotic & $24.694 \mathrm{bA}$ & $23.922 b B$ & 24.308 \\
\hline Prebiotic & $24.672 \mathrm{bA}$ & $23.881 \mathrm{bB}$ & 24.276 \\
\hline Synbiotic & $24.198 \mathrm{cA}$ & $23.340 \mathrm{cB}$ & 23.769 \\
\hline $\mathrm{CV} \%$ & 6.97 & 7.61 & 8.47 \\
\hline \multirow[t]{3}{*}{ Average } & 24.742 & 24.023 & \\
\hline & \multicolumn{2}{|c|}{ Egg Production (\%) } & Ayergos \\
\hline & 9 to 23 weeks & 24 to 39 weeks & Average \\
\hline Control & $90.102 \mathrm{bA}$ & $89.223 \mathrm{bB}$ & 89.663 \\
\hline Antibiotic & $96.021 \mathrm{aA}$ & $92.526 \mathrm{aB}$ & 94.274 \\
\hline Probiotic & $95.981 \mathrm{aA}$ & $92.961 \mathrm{aB}$ & 94.471 \\
\hline Prebiotic & $95.532 \mathrm{aA}$ & $92.763 \mathrm{aB}$ & 94.148 \\
\hline Synbiotic & $96.140 \mathrm{aA}$ & $92.921 \mathrm{aB}$ & 94.531 \\
\hline $\mathrm{CV} \%$ & 5.37 & 6.28 & 7.88 \\
\hline \multirow[t]{3}{*}{ Average } & 94.755 & 92.079 & \\
\hline & \multicolumn{2}{|c|}{ Egg Weight Average (g) } & Ayorequ \\
\hline & 9 to 23 weeks & 24 to 39 weeks & Average \\
\hline Control & $11.03 \mathrm{bB}$ & $12.08 \mathrm{bA}$ & 11.055 \\
\hline Antibiotic & $11.37 \mathrm{aB}$ & $12.92 \mathrm{aA}$ & 12.145 \\
\hline Probiotic & $11.26 \mathrm{aB}$ & $12.82 \mathrm{aA}$ & 12.040 \\
\hline Prebiotic & $11.20 \mathrm{aB}$ & $12.78 \mathrm{aA}$ & 11.991 \\
\hline Synbiotic & $11.35 \mathrm{aB}$ & $12.79 \mathrm{aA}$ & 12.072 \\
\hline $\mathrm{CV} \%$ & 4.57 & 5.24 & 6.21 \\
\hline \multirow[t]{3}{*}{ Average } & 11.242 & 12.678 & \\
\hline & \multicolumn{2}{|c|}{ Egg Mass (g) } & Ayoreor \\
\hline & 9 to 23 weeks & 24 to 39 weeks & Average \\
\hline Control & $9.938 \mathrm{bB}$ & $10.778 \mathrm{bA}$ & 10.358 \\
\hline Antibiotic & $10.917 \mathrm{aB}$ & $11.954 \mathrm{aA}$ & 11.436 \\
\hline Probiotic & $10.807 \mathrm{aB}$ & $11.918 \mathrm{aA}$ & 11.363 \\
\hline Prebiotic & $10.699 \mathrm{aB}$ & $11.855 \mathrm{aA}$ & 11.277 \\
\hline Synbiotic & $10.912 \mathrm{aB}$ & $11.885 \mathrm{aA}$ & 11.398 \\
\hline $\mathrm{CV} \%$ & 6.87 & 6.19 & 5.41 \\
\hline \multirow[t]{3}{*}{ Average } & 10.655 & 11.678 & \\
\hline & \multicolumn{2}{|c|}{ Feed Conversion per Egg Mass (kg/kg) } & Ayorags \\
\hline & 9 to 23 weeks & 24 to 39 weeks & Average \\
\hline Control & $2.292 \mathrm{aB}$ & $2.362 \mathrm{aA}$ & 2.327 \\
\hline Antibiotic & $2.201 \mathrm{bB}$ & $2.228 \mathrm{bA}$ & 2.215 \\
\hline Probiotic & $2.210 \mathrm{bB}$ & $2.246 \mathrm{bA}$ & 2.228 \\
\hline Prebiotic & $2.213 \mathrm{bB}$ & $2.243 \mathrm{bA}$ & 2.228 \\
\hline Synbiotic & $2.208 \mathrm{bB}$ & $2.231 \mathrm{bA}$ & 2.219 \\
\hline
\end{tabular}


TABLE III (continuation)

\begin{tabular}{|c|c|c|c|}
\hline $\mathrm{CV} \%$ & 6.78 & 4.48 & 6.53 \\
\hline Average & 2.225 & 2.262 & \\
\hline & \multicolumn{2}{|c|}{ Feed Conversion per Dozen Eggs (kg/dozen) } & \multirow{2}{*}{ Average } \\
\hline & 9 to 23 weeks & 24 to 39 weeks & \\
\hline Control & $0.251 \mathrm{aB}$ & $0.268 \mathrm{aA}$ & 0.259 \\
\hline Antibiotic & $0.223 \mathrm{bB}$ & $0.241 \mathrm{bA}$ & 0.232 \\
\hline Probiotic & $0.228 \mathrm{bB}$ & $0.238 \mathrm{bA}$ & 0.233 \\
\hline Prebiotic & $0.227 \mathrm{bB}$ & $0.237 \mathrm{bA}$ & 0.232 \\
\hline Synbiotic & $0.225 \mathrm{bB}$ & $0.235 \mathrm{bA}$ & 0.23 \\
\hline $\mathrm{CV} \%$ & 4.59 & 6.38 & 5.32 \\
\hline \multirow[t]{3}{*}{ Average } & 0.231 & 0.244 & \\
\hline & \multicolumn{2}{|c|}{ Viability of the Birds (\%) } & \multirow{2}{*}{ Average } \\
\hline & 9 to 23 weeks & 24 to 39 weeks & \\
\hline Control & 98.61 & 98.61 & 98.61 \\
\hline Antibiotic & 99.16 & 99.16 & 99.16 \\
\hline Probiotic & 99.44 & 99.52 & 99.48 \\
\hline Prebiotic & 99.45 & 99.32 & 99.39 \\
\hline Synbiotic & 99.72 & 99.72 & 99.72 \\
\hline CV \% & 6.34 & 5.21 & 6.11 \\
\hline Average & 99.28 & 99.27 & \\
\hline
\end{tabular}

Averages followed by different lowercase letters in the column and capital in line differ 5\% by Tukey test and $5 \%$ by $\mathrm{F}$ test, respectively; CV - coefficient of variation; Period 1.9 - 23 weeks of age (start of the productive period until the end of the productive peak); Period 2. 24 - 39 weeks of age (end of productive peak until the end of productive period); Antibiotic - Bacitracin Zinc; Prebiotic - the mannanoligosaccharides and $\beta$-glucans based; Probiotic - Bacillussubtilis based; synbiotic - prebiotic + probiotic used.

promoting greater efficiency in improving intestinal quality (Pelícia et al. 2004).

In relation to the feed intake, whereas, as the bird grows older feed intake increases due to the greater weight and greater nutritional demand required by the bird, the incorporation of feed additives in this study consisted of an effective livestock management to reduce feed intake without negatively impacting the overall performance of the lot, especially in the final productive stage.

Lower feed intake was also observed in a research performed by Babazadeh et al. (2011), by using synbiotic and prebiotic in the feed of Japanese quails. After the addition of probiotic, prebiotic and synbiotic in the feed, Nikpiran et al. (2013) observed reduction in quail feed intake when compared to the control treatment.
In the present study, improvement was observed in the integrity of the intestinal mucosa (Table III), which may have allowed greater absorption of nutrients being accompanied by increased production of eggs.

The inclusion of additives was more effective in providing increased egg production between 9 to 23 weeks of age, indicating the enhancing effect on egg production caused by the additives in the first productive period, which is the most productive phase of laying hens. In contrast, the second productive period, where the productive rate of laying hens tends to fall due to the age of the bird, the use of additives reduced this fall and at the same time was able to promote an increased production percentage of eggs compared with the control. 


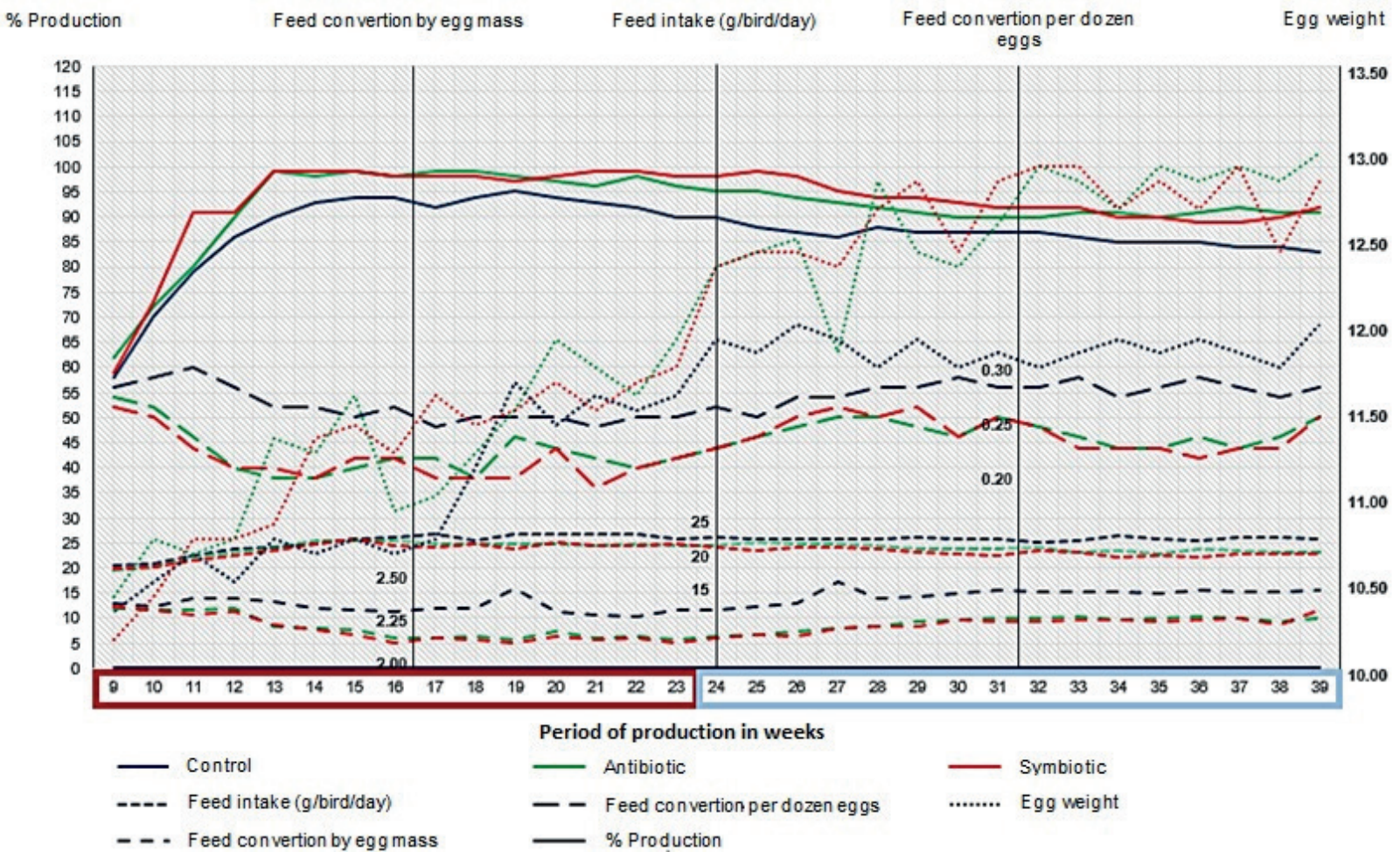

Figure 1 - Performance of quails fed with different additives during two production periods.

By providing prebiotic in the feed of Japanese quails and prebiotic, probiotic and synbiotic in the feed of laying hens, Costa et al. (2008) and Abdelgader et al. (2012), respectively, observed an increase in egg production compared with the control treatment. The use of prebiotic in a research performed by Lemos et al. (2014) and of probiotic by Olgun and Yildiz (2014) also showed an increased production of Japanese quails' eggs.

The inclusion of zootechnical additives in the feed of laying hens allows the rapid development of beneficial bacteria in the digestive tract, and as a result, there is an improvement in intestinal environment, as evidenced by the intestinal morphology results observed in this study, as the increased height and width of villi, the lower crypt depth and greater villus / crypt ratio, increasing the efficiency of the digestive processes and nutrient absorption improving the utilization of protein and energy of the feed (Edens 2003, Pelican et al. 2004, Oliveira et al 2007, Zarei et al. 2011).

The increase of the weight of quail eggs caused by additives is noteworthy, especially in the first productive period where the egg weight is lower due to the age of the bird and considering that the weight of quail eggs, according to Wiermann et al. (2015), is a feature much appreciated by the industrial segment, and according to Bertechini (2013) about $43 \%$ of quail eggs consumed in Brazil are sold pickled, the heavier these eggs the better their utilization.

The mass of the eggs relates egg production with the average weight of the eggs and thus followed the results observed for egg weight average. Although in layers at the end of the productive phase occurs a tendency to increase the mass of eggs, the inclusion of additives potentiated this increase compared to the control. 
The viability of the quails was unaffected. Similar results were found by Babazadeh et al. (2011) who after studying the effects of inclusion of prebiotic, probiotic and synbiotic in the feed of Japanese quails observed no significant effect on the viability of these birds. The viability of Japanese quails was also not influenced after inclusion of synbiotic in the feed in a study conducted by Silva et al. (2012). Lemos et al. (2014) found no influence of inclusion of different levels of prebiotic on this feature.

Feed conversion is a variable that relates feed intake with the production of eggs, therefore variations in feed intake and / or in egg production will determine the improvement or deterioration in feed conversion. In the present study, the improvement in feed conversion $(\mathrm{kg} / \mathrm{dz}$ and $\mathrm{kg} /$ $\mathrm{kg}$ ) followed the behavior observed for feed intake and egg production, which were a reflection of the positive influence on the intestinal integrity promoted by the additives tested throughout the productive period of the quail.

As occurs in laying hens, the conversion is better in the first productive period and worsens during the final stages of production, so this result emphasizes the advantage of using zootechnical additives for the enhancement of improved conversion in the first productive phase of the bird, and especially in the final stages on which the conversion tends to deteriorate.

Similar to that seen in the present study, by providing prebiotic in the feed of Japanese quails Oliveira et al. (2009) also observed an improvement in feed conversion per dozen eggs. The use of a synbiotic by Babazadeh et al. (2011) and prebiotic and probiotic by Nikpiran et al. (2013) in the feed of Japanese quails improved feed conversion per mass. Lemos et al. (2014) after inclusion of prebiotics in the feed of quails observed improvement in feed conversion per mass and per dozen eggs, compared to the control treatment.
Table IV refers to the IRR values (internal rate of return), NPV (net present value) and C/B ratio (cost benefit) of using different additives in the feed of Japanese quails throughout the productive period.

The internal rate of return (IRR) was higher with the inclusion of antibiotics in the feed in relation to the other additives and the control. The net present value (NPV) presented positive values for all treatments.

The internal rate of return expresses the percentage of profitability of the project on the invested capital over its lifespan (Noronha 1987, Hoji 2006). Therefore, the treatment using antibiotic showed higher financial profitability compared with the other treatments. The second most profitable treatment was the one using synbiotic, followed by probiotic, prebiotic and finally the control treatment.

According to Noronha (1987) when the resulting NPV is positive the project is feasible. According Gouvea et al. (2014), the project that produces greater NPV value is the most cost effective option, thus the use of antibiotics in the feed of Japanese quails, which led to the highest NPV (R\$ 117.93), showed higher profitability in relation to the other treatments.

The cost benefit analysis of the use of different additives in Japanese quail feed showed that treatments including antibiotic and synbiotic were the most financially viable in relation to the other

TABLE IV

Financial analysis using different additives in the feed of Japanese quails throughout the productive period (9 to 39 weeks of age).

\begin{tabular}{cccc}
\hline Treatments & IRR & NPV & C/B Ratio \\
\hline Control & $23.7 \%$ & $\mathrm{R} \$ 85.09$ & $\mathrm{R} \$ 1.19$ \\
Antibiotic & $31.5 \%$ & $\mathrm{R} \$ 117.93$ & $\mathrm{R} \$ 1.26$ \\
Probiotico & $30.3 \%$ & $\mathrm{R} \$ 113.58$ & $\mathrm{R} \$ 1.25$ \\
Prebiotic & $30.5 \%$ & $\mathrm{R} \$ 113.95$ & $\mathrm{R} \$ 1.25$ \\
Synbiotic & $30.9 \%$ & $\mathrm{R} \$ 116.38$ & $\mathrm{R} \$ 1.26$ \\
\hline
\end{tabular}

IRR - internal rate of return; NPV - net present value; $C / B$ ratio - cost benefit ratio. 
treatments because for every $\mathrm{R} \$ 1.00$ invested in the production of quail eggs it was obtained $\mathrm{R} \$$ 1.26 in return. Whereas in the control treatment, which had no additive included, for every $\mathrm{R} \$ 1.00$ invested in the production of quail eggs it was obtained R\$ 1.19 in return and in the treatments including prebiotic and probiotic for each $\mathrm{R} \$ 1.00$ invested in the production of quail eggs it was obtained R\$ 1.25 in return.

The financial analysis showed that the use of antibiotic or synbiotic in the feed of Japanese quails is more advantageous than the use of the other additives studied (prebiotics and probiotics). Based on the results observed for performance, this analysis strenghthens the indication for the use of additives for quails throughout the productive period. However, it is important to consider that the additives such as probiotics and prebiotics for being emerging products in the market, when compared with the performance enhencer antibiotics, have yet little competitive prices and financial analysis reflects only the time in which the study was conducted, since the costs of the feed ingredients and additives used have pronounced oscillation in the market.

\section{CONCLUSIONS}

From a zootechnic point of view, it is feasible to include zootechnical additives in the feed of Japanese quails during their entire productive life, aimed at improving intestinal integrity and consequently productive performance, this advantage being more pronounced during the first productive phase of this species of bird.

The incorporation of antibiotic or synbiotic was financially more advantageous compared to the other additives studied (prebiotics and probiotics).

\section{REFERENCES}

ABDELGADER A, AL-FATAFTAH AR AND DAS G. 2012. Effects of dietary Bacillus subtilis and inulin supplementation on performance, eggshell quality, intestinal morphology and microflora composition of laying hens in the late phase of production. Anim F Sci Tech 179(4): 103-111.

BABAZADEH D, VAHDATPOUR T, NIKPIRAN H, JAFARGHOLIPOUR MA AND VAHDATPOUR S. 2011. Effects of probiotic, prebiotic and synbiotic intake on blood enzymes and performance of Japanese quails (Coturnix japonica). Indian J Anim Sci 81(8): 870-874.

BERTECHINI AG. 2012. The quail production. In: XXIV World's Poultry Congress. Salvador: Anais... Salvador, Bahia.

BERTECHINI AG. 2013. Situação atual e perspectiva da coturnicultura industrial. In: V Simpósio Internacional e VI Congresso Brasileiro de Coturnicultura. Lavras: Anais... Lavras, MG.

BUENO R, ALBUQUERQUE R, MURAROLLI VDA, AYA LAH, RAPOSO RS AND BORDIN RA. 2012. Efeito da influência de probiótico sobre a morfologia intestinal de codornas japonesas. Braz J Vet Res Anim Sci 49(2): 111115.

CANTARELLI VS ET AL. 2005. Aditivos e coadjuvantes biológicos na alimentação de suínos. Texto acadêmico. UFLA, p. 5-87.

COSTA FGP, NOBRE IS, SILVA LPG, GOULART CC, FIGUEIREDO DF AND RODRIGUES VP. 2008. The use of prebiotic and organic minerals in rations for japonese laying quail. Int J Poult Sci 7(4): 339-343.

ÇAKIR S ET AL. 2008. Use of combined probiotic-prebiotic, organic acid and avilamycin in diets of Japanese quails. Revue Méd Vét 159(11): 565-569.

EDENS FW. 2003. An alternative for antibiotic use in poultry: probiotics. Rev Bras Cienc Avic 5(2): 75-97.

FLICKINGER EA, VAN LOO J AND FAHEY JR GC. 2003. Nutritional responses to the presence of inulin and oligofructose in the diets of domesticated animals: a review. Crit Rev Food Sci 43:19-60.

FURLAN RL, MACARI M AND LUQUETTI BC. 2004. Como avaliar os efeitos do uso de prebióticos, probióticos e flora de exclusão competitiva. In: Simpósio técnico de incubação, matrizes de corte e nutrição, 2004, Balneário Camboriú, Santa Catarina: Anais, p. 6-28.

GOUVEA A ET AL. 2014. Análise econômica da produção de Trichogramma pretiosum Riley em diferentes escalas. Entomo Brasilis 7(1): 41-47.

HOJI M. 2006. Administração Financeira: uma abordagem prática. $5^{\mathrm{a}}$ ed., São Paulo: Atlas, 525 p.

HUYGHEBAERT G AND GROOTE G. 1997. The bioefficacy of zinc bacitracin in pratical diets for broilers and laying hens. Poult Sci 76(6): 849-856.

IBGE - INSTITUTO BRASILEIRO DE GEOGRAFIA E ESTATÍSTICA. 2014. Sistema IBGE de recuperação automática. Estatística de produção pecuária. Disponível 
em: http://www.ibge.com.br. Acesso em 11 de janeiro de 2016.

IBRAHIM ZA. 2011. Modulation of immunity and some biological functions of Japanese quail by mannan oligosaccharide and B-glucan administration. Egypt Poult Sci 31(4): 867-882.

KISIELINSKI K, WILLIS S, PRESCHER A, KLOSTERHALFEN B AND SCHUMPELICK VA. 2002. Simple new method to calcule-te small intestine absorptive surfasse in the rat. Clin Exper Medic 2: 131-135.

LEMOS MJ, CALIXTO LFL, LIMA CAR, REIS TL, REGO RS, NAK SY AND AROYCHA RJN. 2014. Níveis de prebiótico na dieta sobre o desempenho e a qualidade de ovos de codornas japonesas. Rev Bras Saúde Prod Anim 15(3): 613-625.

MARQUES HL AND ANTUNES R. 2015. Coturnicultura em expansão. Avicultura Industrial. Ed. 1244, p. 26-32.

MATHEW AG, SUTTON AL AND SCHEIDT AB. 1993. Effect of galactan on selected microbial populations and $\mathrm{pH}$ and volatile fatty acids in the ileum of the weaning pig. J Anim Sci 71: 1503-1509.

NIKPIRAN H, VAHDATPOUR T, BABAZADEH D AND VAHDATPOUR S. 2013. Effects of Saccharomyces cerevisiae, Thepax and their combination on blood enzymes and performance of Japanese quails (Coturnix coturnix). J Anim Plant Sci 23(2): 369-379.

NORONHA JF. 1987. Projetos agropecuários. São Paulo: Atlas, $269 \mathrm{p}$.

OLGUN O AND YILDIZ AO. 2014. Effects of diets including different levels of protein and supplemented with probiotic-enzyme on performance and eggshell quality of laying quails. Turk J Agric - Food Sci Technol 2: 236-241.

OLIVEIRA MC, CANCHERINI LC, GRAVENA RA, RIZZO PV AND MORAES VMB. 2007. Utilização de nutrientes de dietas contendo mananoligossacarídeos e/ou complexo enzimático para frangos de corte. R Bras Zootec 36: 825831.

OLIVEIRA MC, MACHADO MG, GONÇALVES BN, MACEDO CMR AND ASSIS FA. 2009. Dietas com mananoligossacarídeos e níveis reduzidos de cálcio para codornas japonesas. R Bras Zootec 38: 2193-2197.
OLIVEIRA RFM, ZANUSSO JT AND DONZELE JL. 2000. Níveis de energia metabolizável para frangos de corte de 1 a 21 dias de idade mantidos em ambiente de alta temperatura. R Bras Zootec 29: 810-816.

PELICANO ERL, SOUZA PA, SOUZA HBA, FIGUEIREDO DF, BOIAGO MM, CARVALHO SR AND BORDON VF. 2005. Intestinal mucosa development in broiler chickens fed natural growth promotores. Rev Bras Cienc Avic 7(4): 221-229.

PELÍCIA K ET AL. 2004. Use of prebiotics and probiotics of bacterial and yeast origin for free-range broiler chickens. Rev Bras Cienc Avic 6: 163-169.

PREIS GM, GIRÃO LVC, LARA LJ AND ROSTAGNO MH. 2013. Aditivos melhoradores de desempenho: O que vem por aí? Disponível em: https://pt.ergomix.com/ MA-avicultura/nutricao/artigos/aditivos-melhoradoresdesempenho-vem-t1754/141-p0.htm. Acesso em 12 de agosto de 2015.

ROBERFROID M ET AL. 2010. Prebiotic effects: metabolic and health benefits. Br J Nutr 104: 1-63.

ROSTAGNO HS, ALBINO LFT, DONZELE JL, GOMES PC, OLIVEIRA RF, LOPES DC, FERREIRA AS, BARRETO SLT AND EUCLIDES RF. 2011. Tabelas brasileiras para aves e suínos. Composição de alimentos e exigências nutricionais. UFV, Viçosa, Brasil, 252 p.

SILVA JST, MATOS AS, HADA FH, GRAVENA RA, MARQUES RH AND MORAES VMB. 2012. Simbiótico e extratos naturais na dieta de codornas japonesas na fase de postura. Ci Anim Bras 13(1): 1-7.

VIOLA ES AND VIEIRA SL. 2007. Suplementação de acidificantes orgânicos e inorgânicos em dietas para frangos de corte: desempenho zootécnico e morfologia intestinal. R Bras Zootec 36(4): 1097-1104.

WIERMANN LA, DIANA TF, BATISTON NR, BRIGHENTI CRG AND REIS RS. 2015. Comparação de características dos ovos de codorna processados manualmente e industrialmente. In: XXV Congresso Brasileiro de Zootecnia, Anais... Zootec 2015, Fortaleza, CE.

ZAREI M, EHSANI M AND TORKI M. 2011. Dietary inclusion of probiotics, prebiotics and synbiotic and evaluating performance of laying hens. Ameri J Agric Biolo Sci 6(2): 249-255. 